\title{
PHYTOCHEMICAL CONSTITUENTS AND ANTIOXIDANT EFFECT OF SOLANUM ROSTRATUM SPECIES FROM ALGERIA
}

\author{
TEBBOUB OMAR ${ }^{1}$, LABIB NOMAN ${ }^{2,4 *}$, BOUHROUME MOHAMED ${ }^{1}$, FEYZA OKE ALTUNTAS ${ }^{3}$, IBRAHIM DEMIRTAS ${ }^{2}$ \\ ${ }^{1}$ Unité de recherché Valorisation des Ressources Naturelles, Molécules Bioactives et Analyses Physicochimiques et Biologiques, Université \\ frères Mentouri, Constantine, Algérie. ${ }^{2}$ Department of Chemistry, Laboratory of Plant Research, Faculty of Science, Cankiri Karatekin \\ University, Cankiri, Turkey. ${ }^{3}$ Department of Biology, Faculty of Science, Gazi University, Ankara, Turkey, ${ }^{4}$ Laboratory of Pharmacognosy, \\ Department of Pharmacy, Faculty of Medicine and Health Sciences, Taiz University, Taiz, Yemen. Email: labibnomanali@gmail.com
}

Received: 25 January 2018, Revised and Accepted: 03 march 2018

\section{ABSTRACT}

Objective: The aim of this study was to isolate the constituents and evaluate the antioxidant activity of Solanum rostratum Dunal (Solanaceae) from Algeria.

Methods: In this study, phytochemical analyses of the chloroform, ethyl acetate, and $n$-butanol extracts obtained from the aerial parts of $S$. rostratum were performed by column chromatography, thin-layer chromatography, and high-performance liquid chromatography techniques. The antioxidant activity was performed by 2,2-diphenyl-1-picrylhydrazyl scavenging assay method.

Results: The identification and structure elucidation of the isolated compounds were compared with their nuclear magnetic resonance spectra and the literature led to identify one monoterpene glycoside (linalyl- $\beta$-glucopyranoside) (1) and three flavonoid glycosides: Apigenin-7-O-glucoside (2), astragalin (3) and (isorhamnetin-3-O-glucoside (4).

Conclusion: This is the first report on the isolation and structure elucidation of compound (1) (linalyl- $\beta$-glucopyranoside) and compound (2) (apigenin-7-O-glucoside) from this species. In addition, antioxidant effect of the chloroform extract from $S$. rostratum was evaluated. The chloroform extract exhibited the remarkable radical scavenging ability $\left(\mathrm{IC}_{50}=0066 \pm 0.001 \mathrm{mg} / \mathrm{mL}\right)$.

Keywords: Solanum rostratum, Monoterpene glycoside, Flavonoid glycosides, Antioxidant.

(C) 2018 The Authors. Published by Innovare Academic Sciences Pvt Ltd. This is an open access article under the CC BY license (http://creativecommons. org/licenses/by/4. 0/) DOI: http://dx.doi.org/10.22159/ajpcr.2018.v11i6.24951

\section{INTRODUCTION}

Solanaceae family has an economical and medicinal importance [1], it comprising about 2000 species and growing in the tropical and subtropical areas [1]. A phytochemical investigation in this family showed several types of chemical constituents and many traditional uses. Solanum torvum Swartz used in folk medicine as sedative, digestive, hemostatic, and diuretic in the southern areas of China [2]. The main isolated constituents were flavonoids and saponins from the aerial parts [3], along with antiviral isoflavonoid sulfate and steroidal glycosides from the fruits of $S$. torvum [4]. The methanolic extract from the fruit of Solanum lycocarpum was found to inhibit the increase of serum glucose levels in sucrose-loaded rats [5].

Solanum rostratum Dun is a harmful herb, it has widespread existence in North America [6] and has been classifying as quarantine weed for ecosystem and human health [7]. The previous isolation studies showed that $S$. rostratum had alkaloid components: Solasonine, solamargine [8], and methyl protodioscin [9], which cause the toxicity of this species [10]. In addition to exist the phenolic compounds which have various activities against antibacterial, cytotoxic and antioxidant $[11,12]$.

In this study, we report the isolation and characterization of the constituents of $S$. rostratum and evaluation of antioxidant activity of the chloroform extract of this plant.

\section{METHODS}

\section{Plant material}

The aerial parts of $S$. rostratum were collected at the end of April 2009 (flowering stage) in Constantine, Algeria. Fresh aerial parts were dried to constant weight at room temperature.

\section{Chemicals}

Anhydrous sodium carbonate, Folin-Ciocalteu's phenol reagent, and methanol (analytical reagent and high-performance liquid chromatography [HPLC] gradient grade) were purchased from Merck (Darmstadt, Germany), 2,2-diphenyl-1-picrylhydrazyl (DPPH), gallic acid, 2,6-di-tert-butyl-4-methylphenol (BHT), butylated hydroxyanisole (BHA), and dimethylsulphoxide (DMSO) were purchased from SigmaAldrich GmbH (Taufkirchen, Germany). All other chemicals were analytical grade and obtained from either Sigma or Merck.

\section{General experimental procedure}

Nuclear magnetic resonance (NMR) measurements were performed on a Bruker Avance III spectrometer in DMSO-d6 and $\mathrm{CD}_{3} \mathrm{OD}$ $\left({ }^{1} \mathrm{H}: 600 \mathrm{MHz} ;{ }^{13} \mathrm{C}: 150 \mathrm{MHz}\right)$. Chemical shifts were given in ppm with tetramethylsilane as an internal standard. HPLC separations were conducted on a Shimadzu LC-8A series pumping system equipped with a Shimadzu RID-10A refractive index detector and Shimadzu injector on a C18 l-Bondapak column $(30 \mathrm{~cm} \times 7.8 \mathrm{~mm}, 10 \mu \mathrm{m}$ waters, flow rate $2.0 \mathrm{ml} \mathrm{min} \times 1)$. The absorbance measurements for antioxidant activity were recorded using the ultraviolet and visible spectrophotometer Rayleigh ultraviolet (UV)-2601, BRAIC Co. Ltd., Beijing, China.

\section{Extraction and isolation}

The aerial parts of $S$. rostratum (1430 g) were crushed and macerated 3 times with $80 \%$ aqueous methanol, each for $72 \mathrm{~h}$ at room temperature, and the solvent was removed in vacuo to yield a crude extract (269.2 g). The crude extract was dissolved in $800 \mathrm{ml} \mathrm{H}_{2} \mathrm{O}$ and extracted with petroleum ether, chloroform, ethyl acetate, and $n$-butanol, respectively. The chloroform extract (2.1g) was subjected to column chromatography on silica gel using a $\mathrm{CHCl}_{3}-\mathrm{MeOH}$ (from 100:0 to 0:100, v/v) to provide 26 fractions, and the fraction $13(84.1 \mathrm{mg})$ was purified on preparative C18 
HPLC column with a gradient of $\mathrm{MeOH}-\mathrm{H}_{2} \mathrm{O}(30: 70, \mathrm{v} / \mathrm{v})$ to yield compound (1) (3 mg). The ethyl acetate extract ( $5.44 \mathrm{~g}$ ) was chromatographed on silica gel eluted with a gradient of petroleum ether-diethyl ether (from 100:0 to $0: 100, \mathrm{v} / \mathrm{v}$ ) to obtain 17 fractions, the fraction $9(812 \mathrm{mg}$ ) performed on flash columneluted gradually with a $\mathrm{CHCl}_{3}-\mathrm{MeOH}$ (from $100: 0$ to $0: 100, v / v)$ to afford 13 subfractions, and the precipitate from subfraction 7 (128 mg) was purified by thin-layer chromatography (TLC) eluted with aEtOAc-MeOH- $\mathrm{H}_{2} \mathrm{O}(8: 1: 1, \mathrm{v} / \mathrm{v} / \mathrm{v})$ to yield compounds 2 $(9 \mathrm{mg})$ and 3 (11 mg). Fractionation of the n-butanol extract (17 g) was carried out by column chromatography on silica gel, eluted with a gradient of EtOAc-MeOH (from 100:0 to 0:100, v/v) to yield 21 fractions, and the yellow precipitate from fraction 17 (193 $\mathrm{mg}$ ) was purified by TLC eluted with a EtOAc- $\mathrm{MeOH}-\mathrm{H}_{2} \mathrm{O}(8: 1: 1, \mathrm{v} / \mathrm{v} / \mathrm{v})$ to yield compound (4) (5 mg).

\section{Antioxidant activity \\ DPPH radical scavenging assay}

Radical scavenging activity was determined by a spectrophotometric method based on the reduction of a methanol solution of DPPH using the method of Blois (1958) [13], with some modifications [14]. The sample solutions were added to $0.004 \%$ methanol solution of DPPH. The mixture was shaken vigorously and left to stand at room temperature for $30 \mathrm{~min}$ in the dark. The absorbance was measured at $517 \mathrm{~nm}$ against a blank by a spectrophotometer (Rayleigh, UV-2601). Scavenging of DPPH radical was calculated according to the following formula:

Radical scavenging $\%=\left[\left(A_{\text {control }}-A_{\text {sample }}\right) / A_{\text {control }}\right] \times 100$

where $A_{\text {control }}$ is the absorbance of the control reaction (containing all reagents except the test compound), and $A_{\text {sample }}$ is the absorbance of the test compound. DPPH scavenging activity was expressed as IC $_{50}$ values $(\mathrm{mg} / \mathrm{ml})$ for comparison. The $\mathrm{IC}_{50}$ value of each sample was defined as the concentration of sample required for a $50 \%$ decrease in absorbance of the blank. BHT and BHA were used as positive controls.

\section{Determination of total phenolic contents}

Total phenolic content of the chloroform extract was analyzed using the Folin-Ciocalteu reagent according to the method of Singleton and Rossi [15] using gallic acid as standard, with some modifications [16]. The extract solution was mixed with $0.2 \mathrm{ml}$ of $50 \%$ Folin-Ciocalteu reagent and allowed to react for $3 \mathrm{~min}$, and $1 \mathrm{ml}$ aqueous solution of $2 \% \mathrm{Na}_{2} \mathrm{CO}_{3}$ was added. At the end of incubation for $45 \mathrm{~min}$ at room temperature, the absorbance of each mixture was measured at $760 \mathrm{~nm}$. The same procedure was also applied to the standard solutions of gallic acid. Total phenolic content was expressed as $\mu$ g gallic acid equivalents per mg of the extract.

\section{Statistical analysis}

All experiments were done in triplicate. The results were expressed as means \pm standard deviations. Statistical analyses were performed using the SPSS 11.5 (SPSS, Chicago, IL). Differences among means were done by analysis of variance, and averages were compared using the Tukey test. The level of statistical significance was taken at $\mathrm{p}<0.01$.

\section{RESULTS}

The four compounds isolated from $S$. rostratum species which grow in Algeria were identified as linalyl- $\beta$-glucopyranoside (1) [17], apigenin7-O-glucoside (2) [18], astragalin (3) [10], and isorhamnetin-3-Oglucoside (4) [19] (Fig. 1), by comparing their spectra data with those reported in the literature.

\section{Compound 1 (Linalyl- $\beta$-glucopyranoside):}

It is isolated as white viscous liquid. The ${ }^{1} \mathrm{H}$ NMR and heteronuclear single quantum correlation spectra of 1 (Figs. 2 and 3) exhibited signal attributed to one methyl at $\delta 1.39$ (3H, s, H-10); two methyls at $\delta 1.61(3 \mathrm{H}, \mathrm{s}, \mathrm{H}-8)$ and $1.69(3 \mathrm{H}, \mathrm{s}, \mathrm{H}-9)$ which may connect with an olefinic carbon according to the downfield shift of the methyls; two olefinic methine signals with a proton at $\delta 5.99(1 \mathrm{H}, \mathrm{dd}, \mathrm{J}=17.5$, $11.0 \mathrm{~Hz}, \mathrm{H}-2)$ and $5.12(1 \mathrm{H}, \mathrm{br} \mathrm{t}, \mathrm{J}=7.0 \mathrm{~Hz}, \mathrm{H}-6)$; two olefinic methylene signals with a proton at $\delta 5.22(1 \mathrm{H}, \mathrm{d}, \mathrm{J}=11.0 \mathrm{~Hz}, \mathrm{H}-1-\mathrm{a})$ and $5.27(1 \mathrm{H}, \mathrm{d}$, $\mathrm{J}=17.5 \mathrm{~Hz}, \mathrm{H}-1-\mathrm{b})$; and two methylene groups with signals at $\delta 1.61(2 \mathrm{H}$, $\mathrm{m}, \mathrm{H}-4)$ and $2.06(2 \mathrm{H}, \mathrm{m}, \mathrm{H}-5)$. One anomeric proton signal at $\delta 4.36(\mathrm{~d}$, $\mathrm{J}=7.5 \mathrm{~Hz}, \mathrm{H}-1^{\prime}$ ) corresponding to glucosyl moiety. One anomeric proton signal at $\delta 4.36\left(\mathrm{~d}, \mathrm{~J}=7.5 \mathrm{~Hz}, \mathrm{H}-1^{\prime}\right)$, and five protons at $\delta 3.18\left(\mathrm{~m}, \mathrm{H}-2^{\prime}\right)$, 3.29 (m, H-3'), 3.39 (m, H-4'), 3.19 (m, H-5'), 3.65 (dd, J= 11.8, 5.4 Hz, H-6'-b), and 3.81 (dd, J= 11.8, 2.2 Hz, H-6'-a) corresponding to glucosyl moiety. The sugar linkage and methyl group in position 10 were determined on the basis of the HMBC correlations of the quaternary carbon at $\delta 88.8$ (C-3) (Figs. 4 and 5). ${ }^{13} \mathrm{C}$ NMR (MeOD, 150MHz): 16.0 (C-8), 21.9 (C-10), 22.7 (C-5), 24.0 (C-9), 40.0 (C-4), 61.4 (C-6'), 70.2 (C-4'), 73.0 (C-2'), 76.8 (C-5'), 77.0 (C-3'), 88.8 (C-3), 98.7 (C-1'), 114.4 (C-1), 124.4 (C-6), 130.6 (C-7), 142.5 (C-2).

Compound 2 (Apigenine-7-O-glucoside): yellow powder; $\mathrm{C}_{21} \mathrm{H}_{20} \mathrm{O}_{10}$; ${ }^{1} \mathrm{H}-\mathrm{NMR}$ (MeOD, 600MHz): 3.27 4.10 (6H, H-2" H-6", m), 5.78 (1H, d, J $\left.=7.7 \mathrm{~Hz}, \mathrm{H}-1^{\prime \prime}\right), 6.64(1 \mathrm{H}, \mathrm{d}, \mathrm{J}=2.0 \mathrm{~Hz}, \mathrm{H}-8), 6.67(1 \mathrm{H}, \mathrm{s}, \mathrm{H}-3), 6.82(1 \mathrm{H}, \mathrm{d}$, $\mathrm{J}=2.0 \mathrm{~Hz}, \mathrm{H}-6), 6.94\left(2 \mathrm{H}, \mathrm{d}, \mathrm{J}=8.5 \mathrm{~Hz}, \mathrm{H}-3^{\prime}, \mathrm{H}-5^{\prime}\right), 7.91(2 \mathrm{H}, \mathrm{d}, \mathrm{J}=8.5 \mathrm{~Hz}$, H-2', H-6'); ${ }^{13}$ C-NMR (MeOD, 150MHz): 61.65 (C-6"), 70.89 (C-4'”), 74.34 (C-2”), 76.29 (C-3"), 77.90 (C-5”), 95.37 (C-8), 100.49 (C-6), 103.29 (C-3), 103.30 (C-1"), 109.22 (C-10), 116.22 (C-3', C-5'), 123.40 (C-1'), 128.20 (C-2',C-6'), 159.73 (C-4'), 160,25 (C-9), 162.10 (C-7), 163.85 (C5), $164.20(\mathrm{C}-2), \delta 181.53(\mathrm{C}-4)$.

Compound 3 (Astragalin): yellow powder; $\mathrm{C}_{21} \mathrm{H}_{20} \mathrm{O}_{11} ;{ }^{1} \mathrm{H}-\mathrm{NMR}$ (DMSO-d6, 600MHz): 3.22 3.73 (6H, H-2" H-6", m), 5.42 (1H, d, J = 7.53 Hz, H-1"), $6.18(1 \mathrm{H}, \mathrm{d}, \mathrm{J}=2.01 \mathrm{~Hz}, \mathrm{H}-6), 6.36(1 \mathrm{H}, \mathrm{d}, \mathrm{J}=2.01 \mathrm{~Hz}, \mathrm{H}-8), 6.90(2 \mathrm{H}, \mathrm{d}$, $\left.\mathrm{J}=8.78 \mathrm{~Hz}, \mathrm{H}-5^{\prime}, \mathrm{H}-3^{\prime}\right), 7.08$ (2H, dd, J = $8.78 \mathrm{~Hz}, \mathrm{H}-6$ ', H-2'); ${ }^{13} \mathrm{C}-\mathrm{NMR}$ (DMSO-d6, 150MHz): 61.32 (C-6"), 69.95 (C-4"), 74.33 (C-2"), 76.68 (C3"), 77.01 (C-5”), 96.76 (C-8), 99.28 (C-6), 102.83 (C-1"), 103.42 (C-10), 114.78 (C-3', 5'), 121.44 (C-1'), 130.84 (C-2', 6'), 133.97 (C-3), 157.28 (C2),157.47 (C-9), 160.21 (C-4'), 163.35 (C-5), 165.89 (C-7), 178.03 (C-4)

Compound 4 (Isorhamnetin-3-0-glucoside): yellow powder; $\mathrm{C}_{22} \mathrm{H}_{22} \mathrm{O}_{12}$; ${ }^{1} \mathrm{H}-\mathrm{NMR}$ (DMSO-d6, 600MHz): 3.68 3.09 (6H, H-2" H-6", m), 3.83 (3H, s, 3'- $\left.\mathrm{OCH}_{3}\right), 5.42\left(1 \mathrm{H}, \mathrm{d}, \mathrm{J}=7.53 \mathrm{~Hz}, \mathrm{H}-1^{\prime \prime}\right), 5.90(1 \mathrm{H}, \mathrm{d}, \mathrm{J}=2.26 \mathrm{~Hz}, \mathrm{H}-6)$, $6.00(1 \mathrm{H}, \mathrm{d}, \mathrm{J}=2.26 \mathrm{~Hz}, \mathrm{H}-8), 6.87\left(1 \mathrm{H}, \mathrm{d}, \mathrm{J}=8.78 \mathrm{~Hz}, \mathrm{H}-5^{\prime}\right), 7.98(1 \mathrm{H}, \mathrm{dd}, \mathrm{J}$ = 8.78-2.50 Hz, H-6'), $8.00\left(1 \mathrm{H}, \mathrm{d}, \mathrm{J}=2.50 \mathrm{~Hz}, \mathrm{H}-2^{\prime}\right) ;{ }^{13} \mathrm{C}-\mathrm{NMR}$ (DMSO-d6, 150MHz): 56.88 (4'-OCH3), 72.93 (C-2”), 73.70 (C-3”), 69.93 (C-4”), 77.81 (C-5"), 60.91 (C-6"), 95.60 (C-8), 99.68 (C-6), 101.35 (C-1"), 103.80 (C-10), 113.50 (C-2'), 115.55 (C-5'), 121.59 (C-1'), 131.16 (C-6'), 133.50 (C-3), 147.59 (C-4'),149.99 (C-3'), 155.78 (C-2), 156.60 (C-9), 161.30 (C-5), 165.10 (C-7), 177.70 (C-4).

\section{Antioxidant activity and total phenolic content}

DPPH radical scavenging activities of the chloroform extract $\left(\mathrm{CHCl}_{3}\right)$ and the synthetic agents are given in Table 1 . According to these $\mathrm{IC}_{50}$ values, the $\mathrm{DPPH}$ radical scavenging abilities among the samples were in the order of $\mathrm{BHA}>\mathrm{BHT}>\mathrm{CHCl}_{3}(\mathrm{p}<0.01)$. The $\mathrm{IC}_{50}$ value for DPPH radical scavenging of the chloroform extract was determined as $0.066 \pm 0.001 \mathrm{mg} / \mathrm{ml}$. Fig. 6 shows the dose-response curves of the DPPH radical scavenging activities of the crude chloroform extract from $S$. rostratum and the synthetic antioxidants. On the other hand, the content of total phenolic compounds in the chloroform extract was found as $88.45 \pm 0.34 \mu \mathrm{g} / \mathrm{mg}$.

Table 1: Antioxidant activities of chloroform extract from Solanum rostratum ${ }^{1}$

\begin{tabular}{|c|c|c|}
\hline \multirow[t]{2}{*}{ Material } & DPPH & Total phenolic content \\
\hline & $\mathrm{IC}_{50}(\mathrm{mg} / \mathrm{ml})$ & ( $\mu$ gGAE/mg of extract) \\
\hline Cloroform extract & $0.066 \pm 0.001^{c}$ & $88.45 \pm 0.34$ \\
\hline BHT & $0.023 \pm 0.001^{\mathrm{b}}$ & NS \\
\hline BHA & $0.003 \pm 0.000^{\mathrm{a}}$ & NS \\
\hline
\end{tabular}

${ }^{1}$ Values represent averages \pm standard deviations for triplicate experiments.

Values in the same column with different superscripts are significantly $(\mathrm{p}<0.01)$ different. NS: Not studied. DPPH: 2,2-diphenyl-1-picrylhydrazyl,

BHT: 2,6-di-tert-butyl-4-methylphenol, BHA: Butylated hydroxyanisole 


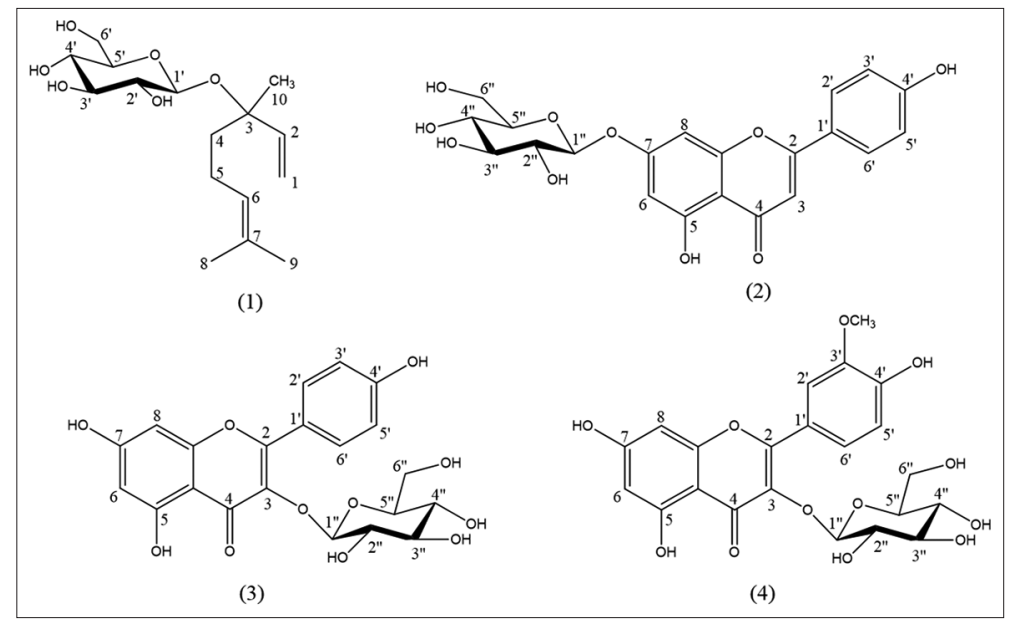

Fig. 1: Structures of the isolated compounds 1-4

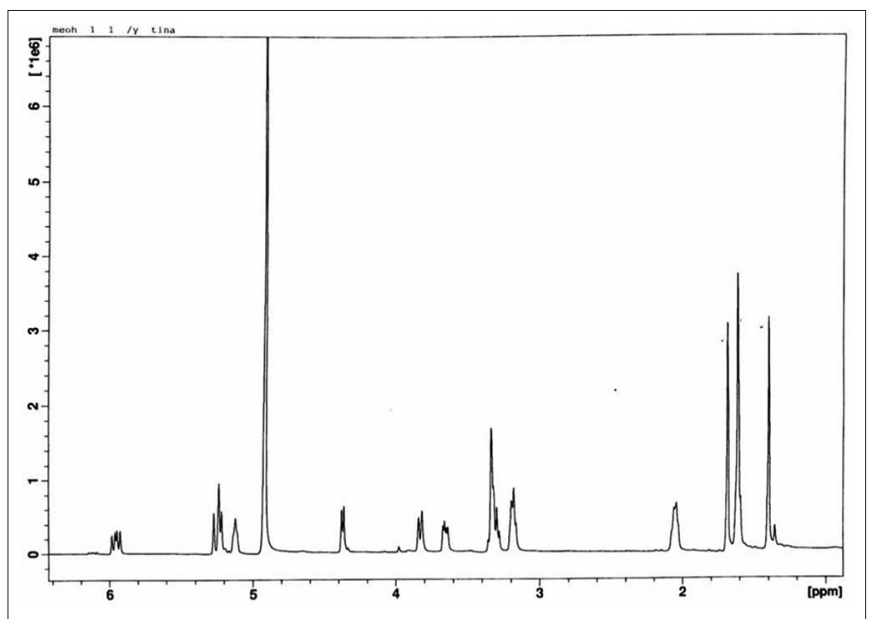

Fig. 2: ${ }^{1} \mathrm{H}$-nuclear magnetic resonance spectrum of compound 1

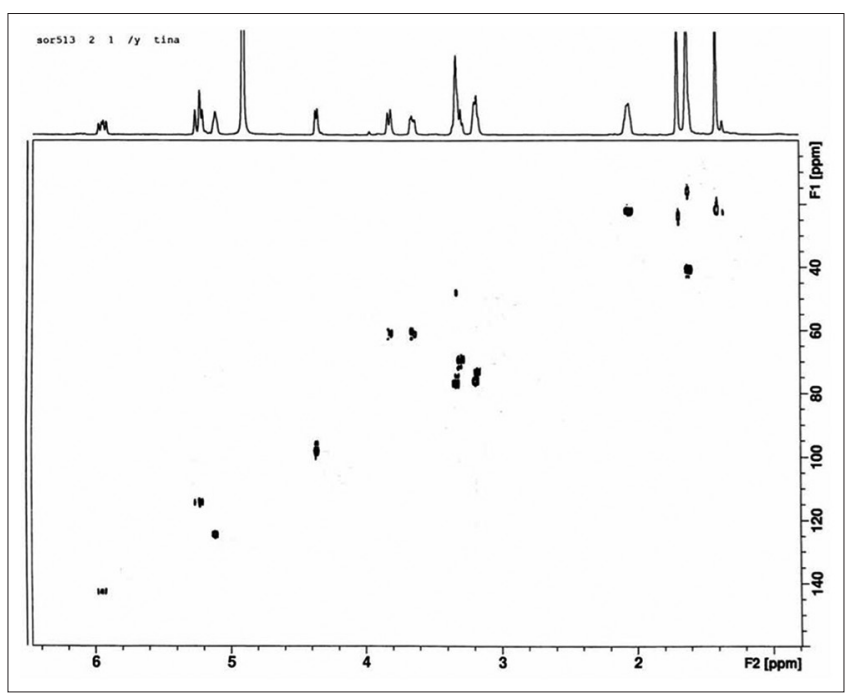

Fig. 3: Heteronuclear single quantum correlation spectrum of compound 1

\section{DISCUSSION}

Phytochemical analyses of the chloroform, ethyl acetate, and $n$-butanol extracts obtained from the aerial parts of $S$. rostratum led to the isolation of three flavonoid glycosides and monoterpene glycoside.

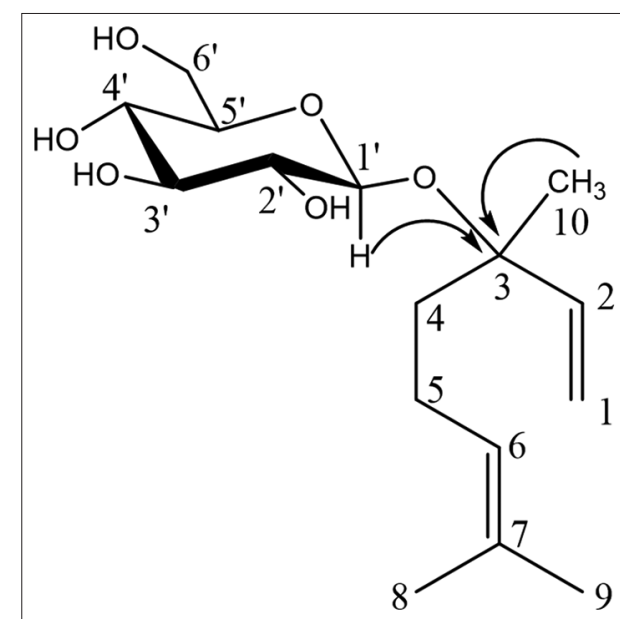

Fig. 4: Selected HMBC $(\rightarrow)$ correlations of compound (1)

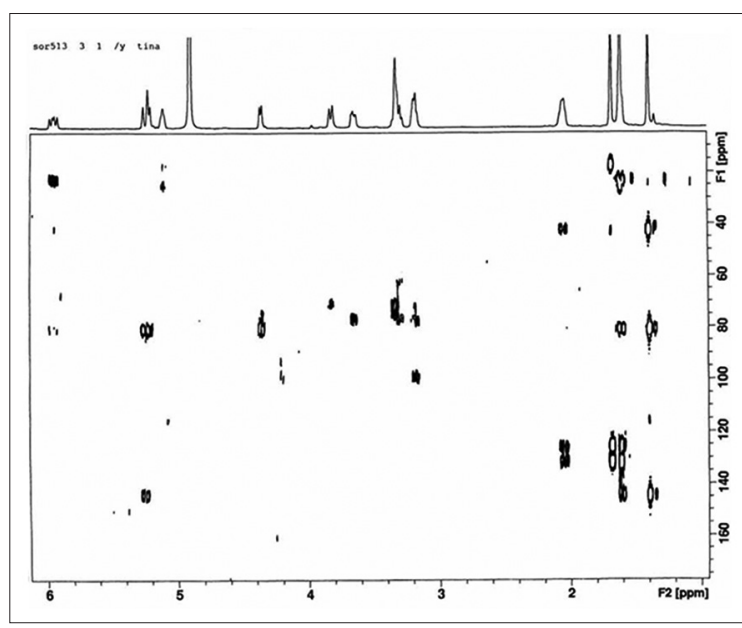

Fig. 5: HMBC Spectrum of Compound 1

One of the aims of this study was to compare the constituents of $S$. rostratum species which grow in Algeria with the other species in different regions. Flavonoids and saponins are the most common isolated compounds which have been reported from the Chinese species S. Rostratum [20]. However, the phytochemical study of the Mexican medical plant $S$. rostratum Dun led to isolated one saponin (methyl protodioscin) [9]. S. rostratum species which grow in Azerbaidzhan 


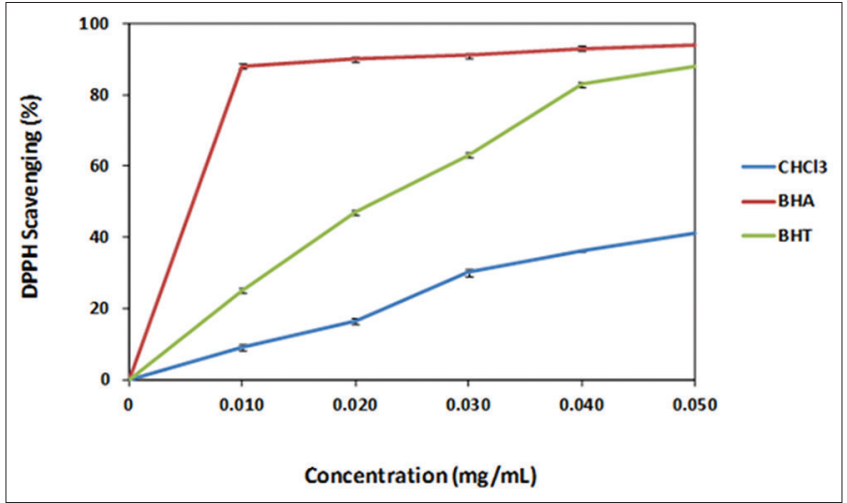

Fig. 6: 2,2-diphenyl-1-picrylhydrazyl scavenging activities of the samples at the tested concentrations

was collected in the Stepanakert region, and two glycosidic alkaloid compounds were obtained and identified as solasonine and solamargine.

In comparison to our results with the previous studies, it showed that the $S$ rostratum Dunal from China also produces compounds, isorhamnetin3-O-glucoside and astragalin [10,19]. While compound (1) (Linalyl$\beta$-glucopyranoside) is isolated for the first time from Algerian species $\mathrm{S}$. rostratum and from the genus Solanum. In addition, this is the first report on the isolation and structure elucidation of compound (2) (Apigenine7-O-glucoside) from this plant. The environmental factors are able to change or produce different secondary metabolites in the same plant species growing under different environmental conditions [21-27]. Thus, the deference of isolated compounds of $S$. rostratum species from different regions probably refers to the environment diversity, such as water availability, temperature, soil, and solar radiation [28-32]

Several studies have been reported on the antioxidant effects of different Solanum species [33,34]. Compound (1) (linalyl- $\beta$-glucopyranoside) was isolated from the chloroform extract which showed the significant antioxidant activity. Similar to our study, Hao et al. [35] reported that the different extraction fractions (ethyl acetate, n-butanol, petroleum ether, and water) of $S$. rostratum had strong antioxidant activities. In another study, the four methanolic extracts (roots, leaves, flowers, and fruits) from this species exhibited the significant inhibitions against the DPPH radical between 86.76 and $90.24 \%$ [36]. Since phenolic compounds are the most important groups of plant secondary metabolites that have diverse biological functions including antioxidant effects [37], the total phenolic content of the extract from $S$. rostratum was also determined. The results showed that chloroform extract of $S$. rostratum had a high amount of total phenolic content.

\section{CONCLUSION}

In this study, four compounds (linalyl- $\beta$-glucopyranoside, apigenin-7$O$-glucoside, astragalin, and isorhamnetin-3-O-glucoside) were isolated from $S$. rostratum species which grow in Algeria. This is the first report on the isolation and structure elucidation of linalyl- $\beta$-glucopyranoside and apigenin-7-O-glucoside from this plant. Furthermore, in this study, the chloroform extract from this plant was evaluated for its antioxidant effect and the results showed that the chloroform extract was remarkable radical scavenger.

\section{ACKNOWLEDGMENT}

This study was supported by the Ministere de l'Enseignement Superieur et de la Recherche Scientifique (MESRES, Alger, Algeria), Turkish State Planning Organization (grant number DPT2010K120720], and Cankiri Karatekin University.

\section{AUTHOR'S CONTRIBUTIONS}

All the authors have contributed equally.

\section{CONFLICT OF INTERESTS}

The authors declared no conflicts of interest.

\section{REFERENCES}

1. Yousafa Z, Wanga Y, Baydounc E. Phytochemistry and pharmacological studies on Solanum torvum Swartz. J Appl Pharm Sci 2013;3:152-60.

2. Zhu ZY, Gao L, Wang JK. Illustrated Handbook for Medicinal Materials from Nature in Yunnan [M]. Vol. 2. Kunming: Yunnan Science and Technology Press; 2003. p. 121.

3. Yuan-Yuan L, Jian-Guang L, Ling-Yi1 K. Chemical constituents from Solanum torvum. Chinese J Nat Med 2011;9:30-2.

4. Arthan D, Svasti J, Kittakoop P, Pittayakhachonwut D, Tanticharoen M, Thebtaranonth Y, et al. Antiviral isoflavonoid sulfate and steroidal glycosides from the fruits of Solanum torvum. Phytochemistry 2002;59:459-63

5. Nakamura S, Hongo M, Sugimoto S, Matsuda H, Yoshikawa M. Steroidal saponins and pseudoalkaloid oligoglycoside from Brazilian natural medicine, "fruta do lobo" (fruit of Solanum lycocarpum). Phytochemistry 2008;69:1565-72.

6. Bassett I, Munro D. The biology of Canadian weeds. Solanum carolinense L. and Solanum rostratum Dunal. Can J Plant Sci 1986;66:977-91.

7. Guan GQ, Gao DC, Li WY, Ye J, Xin XG, Li SD. A quarantine weed: Solanum rostratum. Plant Quar 1984;4:25-8.

8. Novruzov E, Aslanov S, Ismailov N. Glycosidic alkaloids of Solanum rostratum. Chem Nat Compd 1973;9:659.

9. Bah M, Gutierrez DM, Escobedo C, Mendoza S, Rojas JI, Rojas A. Methylprotodioscin from the Mexican medical plant Solanum rostratum (Solanaceae). Biochem Syst Ecol 2004;32:197-202.

10. Huang HJ, Ling TJ, Wang HM, Cao AC, Zhang CX, Wei SH, et al. One new flavonoid from Solanum rostratum. Nat Prod Res 2017;31:1831-5.

11. Morais MG, da Costa GA, Aleixo ÁA, de Oliveira GT, Alves LF, DuarteAlmeida JM, et al. Antioxidant, antibacterial and cytotoxic potential of the ripe fruits of Solanum lycocarpum A. St. Hil. (Solanaceae). Nat Prod Res 2015;29:480-3.

12. Ombra MN, Fratianni F, Granese T, Cardinale F, Cozzolino A, Nazzaro F, et al. In vitro antioxidant, antimicrobial and anti-proliferative activities of purple potato extracts (Solanum tuberosum cv vitelotte noire) following simulated gastro-intestinal digestion. Nat Prod Res 2015;29:1087-91.

13. Blois MS. Antioxidant determinations by the use of a stable free radical. Nature 1958;181:1199-200.

14. Oke-Altuntas F, Aslim B, Duman H, Kartal M. Comparative evaluation of total phenolic/carotenoid contents, chlorogenic acid/rutin profiles, and antioxidant properties of two Prangos species (P. uechtritzii and P. pabularia). Int J Pharm Pharm Sci 2016;8:284-8.

15. Singleton V, Rossi JA. Colorimetry of total phenolics with phosphomolybdic-phosphotungstic acid reagents. Am J Enol Vitic 1965;16:144-58.

16. Yegenoglu H, Aslim B, Oke F. Comparison of antioxidant capacities of Ganoderma lucidum (Curtis) P. karst and Funalia trogii (Berk.) Bondartsev and Singer by using different in vitro methods. J Med Food 2011;14:512-6.

17. Al-Massarani SM, El Gamal AA, Abd El Halim MF, Al-Said MS. New acyclic secondary metabolites from the biologically active fraction of Albizia lebbeck flowers. Saudi Pharm J 2016;25:110-9.

18. Ibrahim TA, El-hela AA, Abd Elhady NM,Abo-Elftoh NM. Phytochemical composition, in vitro antioxidant and cytotoxic activities of seeds of Convolvulus Arvensis Linn. Int J Pharm Biosci 2016;7:107-16.

19. Chang L, Shao Q, Xi X, Chub Q, Wei Y. Separation of four flavonol glycosides from Solanum rostratum Dunal using aqueous twophase flotation 2 followed by preparative high-performance liquid 3 chromatography. J Sep Sci 2016;40:804-12.

20. Hao LJ, Wang S, Zhu JJ, Wang ZM, Wei SH. Chemical constituents from Solanum rostratum. Zhongguo Zhong Yao Za Zhi 2014;39:2034-8.

21. Sampaio BL, Edrada-Ebel R, Da Costa FB. Effect of the environment on the secondary metabolic profile of Tithonia diversifolia: A model for environmental metabolomics of plants. Sci Rep 2016;6:29265.

22. Pavarini DP, Pavarini SP, Niehues M, Lopes NP. Exogenous influences on plant secondary metabolite levels. Anim Feed Sci Technol 2012;176:5-16.

23. Gutbrodt B, Dorn S, Unsicker SB, Mody K. Species-specific responses of herbivores to within-plant and environmentally mediated betweenplant variability in plant chemistry. Chemoecology 2012;22:101-11.

24. Oh MM, Trick HN, Rajashekar CB. Secondary metabolism and antioxidants are involved in environmental adaptation and stress 
tolerance in lettuce. J Plant Physiol 2009;166:180-91.

25. Theis N, Lerdau M. The evolution of function in plant secondary metabolites. Int J Plant Sci 2003;164:S93-102.

26. Bennett RN, Wallsgrove RM. Secondary metabolites in plant defence mechanisms. New Phytol 1994;127:617-33.

27. Wink M. Plant breeding: Importance of plant secondary metabolites for protection against pathogens and herbivores. Theor Appl Genet 1988;75:225-33.

28. Ramakrishna A, Ravishankar GA. Influence of abiotic stress signals on secondary metabolites in plants. Plant Signal Behav 2011;6:1720-31.

29. Arbona V, Manzi M, Ollas CD, Gómez-Cadenas A. Metabolomics as a tool to investigate abiotic stress tolerance in plants. Int $\mathrm{J}$ Mol Sci $2013 ; 14: 4885-911$

30. Shulaev V, Cortes D, Miller G, Mittler R. Metabolomics for plant stress response. Physiol Plant 2008;132:199-208.

31. Graham D, Patterson BD. Responses of plants to low, nonfreezing temperatures: Proteins, metabolism, and acclimation. Annu Rev Plant Physiol 1982;33:347-72.
32. Jakobsen H, Olsen C. Influence of climatic factors on emission of flower volatiles in situ. Planta 1994;192:365-71.

33. Taie H, Abd-Alla H, Ali S, Aly H. Chemical composition and biological activities of two Solanum tuberosum cultivars grown in Egypt. Int J Pharm Pharm Sci 2015;7:311-20.

34. Sudheesh S, Sandhya C, Koshy AS, Vijayalakshmi NR. Antioxidant activity of flavonoids from Solanum melongena. Phytother Res 1999;13:393-6.

35. Hao LJ, Wang S, An YW, Zhu JJ, Wang ZM, Wei SH, Chen JB. Antioxidative properties of different extraction fractions from Solanum rostratum [J]. China J Exp Tradit Med Formulae 2014;20:113-6.

36. Gutiérrez AD, Bah M, Garduño RM, Mendoza DS, Serrano CV. Antiinflammatory and antioxidant activities of methanol extracts and alkaloid fractions of four Mexican medicinal plants of Solanaceae. Afr J Tradit Complement Altern Med 2014;11:259-67.

37. Rice-Evans CA, Miller NJ, Paganga G. Structure-antioxidant activity relationships of flavonoids and phenolic acids. Free Radic Biol Med 1996;20:933-56. 